\title{
How to measure the impact of place marketing activities: a methodological discussion
}

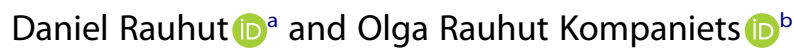

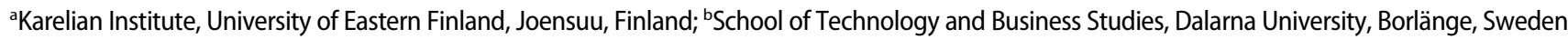

\begin{abstract}
This paper aims to explicate and discuss the main methods of measuring the effects of place marketing. Rather than favouring one method over another a priori, we seek to understand each method on its own terms in order to illuminate key assumptions and hypotheses. Additionally, we compare and contrast the different methods to reveal areas of logical inconsistency.

Generally, the impact of place marketing activities is dominated by fragmented, often single case studies, analysed using qualitative methods. The methods hitherto developed to measure the effect of place marketing activities posit causal mechanisms in line with simple ex ante/ex post comparisons. As place marketing appears to be "political" and policy oriented, the need to understand what happens in the policy process and the context in which marketing activities take place is paramount, we need to unfold the political process so as to understand why and how some place marketing activities work, and others do not.
\end{abstract}

\section{ARTICLE HISTORY}

Received 4 January 2020

Accepted 7 May 2020

\section{KEYWORDS}

Place marketing;

measurement; evaluation

methods; methodology

\section{Introduction}

An increasing amount of resources are spent on place marketing activities, as cities, towns and other places try to attract specific target groups and establish their place as a brand (Kozma, 2006; Metaxas \& Kallioras, 2004; Rauhut Kompaniets \& Rauhut, 2016; Zenker \& Martin, 2011). To what extent this spending has been successful or even pays-off is debated among scholars (Eshuis et al., 2013; Kavaratzis \& Hatch, 2013; Kotler et al., 1999; Zenker \& Martin, 2011). One could expect extensive literature to be available on how place marketing activities are and should be measured, but the literature review by Gertner (2011a, 2011b) does not find this methodological aspect. Vuignier (2017) points out the dominance of fragmented and often single case studies, analysed with qualitative methods, and Lucarelli and Berg (2011, p. 14) conclude that place marketing is "largely based on anecdotic evidence from single case studies".

A recurring theme when reading publications on how to measure the impact(s) of place marketing activities is how difficult it is (Eshuis et al., 2013; Kotler et al., 1999, 1993, 2002; Kozma, 2009; Metaxas, 2010; Ward, 2004). To understand why it is considered to be so difficult to measure the impact of place marketing activities, we need to remember place marketing's trajectories. By using the basic marketing theory of consumer marketing and applying it to places, places become products with a simple marketing logic (Ashworth \& Goodall, 1990; Ashworth \& Voogd, 1990; Warnaby \& Medway, 2013). After all, place marketing follows the "dynamics of buyer-seller relations" (Kotler et al., 1999, p. ix). It is notoriously difficult to measure the impact of marketing activities for consumer goods (Parment, 2018). Hence, as place marketing is "translated from corporate frameworks devised for products, services and companies" (Boisen et al., 2018, p. 5), the impact of place marketing activities suffers from similar impact measurement problems. Consequently, the recurring complaints of how difficult it is to measure place marketing activities become understandable.

When evaluating the effects of an intervention, it is not only important to understand how something has taken place but also why. However, consultants who have little interest in theory and methodology dominate the place marketing field in general (Rauhut Kompaniets \& Rauhut, 2016; Vuignier, 2017). Roberts and Hall (2004) question the applicability of conventional modernist marketing theory when it comes to marketing places. Their theoretical objections relate to examining to what extent it is possible to "consume" a place. Research employing different points of departure has pointed at the difficulties of using the conventional 5P-model for the marketing of places, simply because two of the " $\mathrm{P}$ ' $\mathrm{s}$ " in the model - place and product - become one and the

CONTACT Daniel Rauhut $\otimes$ daniel.rauhut@uef.fi

This article was originally published with errors, which have now been corrected in the online version. Please see Correction (http://doi.org/10.1080/00167223. 2020.1813945).

(c) 2020 The Royal Danish Geographical Society 
same factor (Rauhut Kompaniets \& Rauhut, 2017; Warnaby \& Medway, 2013). The use and definition of "place" vary between different disciplines (for example, marketing and geography), which leads to a theoretical ambiguity and confusion when measuring the effects of an intervention at a defined "place" (Andersson, 2014; Warnaby \& Medway, 2013).

In the literature on how to measure the impact of place branding, there is strong debate as to what indicators should be used (Florek, 2012; Herezniak et al., 2018; Florek et al., 2019; Jorgensen, 2015; Lucarelli, 2012). Using different kinds of indicators (input-outputoutcome-impact) has also been suggested when measuring place branding (Herezniak \& Anders-Morawska, 2015). However, similar discussions are absent regarding what indicators may be used when measuring the effects of place marketing activities. The KPI's (key performance indicators) presented by Parmenter (2007) have been simply rejected by Zenker and Martin (2011) who consider that, e.g.,, tourist overnights and press clippings are too simple indicators to be used when measuring the effects of place marketing activities. Unfortunately, what types of indicators are to be used instead is not presented, and as indicators can reflect input, output and process values, such discussions are needed when measuring interventions (Marques da Costa et al., 2013).

Surprisingly, this problem appears not to have stimulated any major research in the place marketing literature, and this gap calls for further investigation. This paper aims to explicate and discuss the main methods of measuring the effects of place marketing. Rather than favouring one method over another a priori, we seek to understand each method on its own terms, in order to illuminate key assumptions and hypotheses. Only after each method has been considered separately do we compare and contrast the different methods, in order to reveal areas of logical inconsistency. In undertaking this exercise, we seek to provide a sound empirical basis for evaluating the methods that are used to measure the effects of place marketing activities.

\section{Methodological considerations}

The focus in this paper is on place marketing. In the scientific literature, a shift can be noticed from a focus on place marketing towards place branding (Braun \& Zenker, 2010; Govers, 2011; Kavaratzis, 2008). Even though place marketing and place branding are not new phenomena, researchers still struggle with the clarification and definition of these concepts (Boisen et al., 2018; Braun, 2008; Eshuis et al., 2014; Hankinson, 2015; Kavaratzis, 2008; Skinner, 2010). Moreover, given that there are overlaps and similarities between these two concepts, there is a need to differentiate between them. Place marketing as well as place branding focus on places' unique characteristics and help them to attract a target audience (Boisen et al., 2018; Klijn et al., 2012; Rauhut Kompaniets \& Rauhut, 2013). Moreover, both place marketing and place branding require close cooperation with stakeholders, which thus makes these activities "political" and policy oriented (Anholt, 2008; Berglund \& Olsson, 2010; Buss, 2013; Eshuis et al., 2013; Mant, 2008; Rauhut Kompaniets, 2018).

In this paper, we adapt the divisions of Boisen et al. (2018) to distinguish between place marketing and place branding (see Table 1). Contrary to place branding, we are not interested in how the identity, reputation, image or perception of a place is measured; and our interest lies entirely in how the impact of the marketing activities of a certain place is measured. In more detail, the marketing activities we are interested in contain the place marketing characteristics that Boisen et al. (2018) present as demand-driven, focusing on product-market combinations, managing supply and demand, targeting market segments, etc. (see Table 1). Also, of interest to us are the resources that are expended to increase consumer choice, and how place marketing and place branding activities that are used to stimulate a demand for a certain place pay off need to be measured.

As a second issue, we discuss the impact of place marketing activities in this study and not the effectiveness. Effectiveness is about the fulfilment of the aims of an intervention and producing the desired results (Poskhart, 2014), while impact refers to direct and indirect consequences on commerce, employment, incomes or profit, produced by one actor's or entity's action upon another (Weisbrod \& Weisbrod, 1997). Furthermore, the resulting impact of an intervention may be different from its original aims, in both positive and negative terms.

This study forms a literature review that summarizes relevant literature, analyses and synthesizes what is known about the measurement of place marketing activ-

Table 1. Distinguishing between place marketing and place branding.

\begin{tabular}{lll}
\hline & \multicolumn{1}{c}{ Place marketing } & \multicolumn{1}{c}{ Place branding } \\
\hline Driver: & Demand-driven & Identity-driven \\
Approach: & Outside-in (needs) & Inside-out (relevance) \\
Task: & To manage supply and & To manage reputation \\
Mandate: & demand & Image orchestration \\
Budget: & Product-market & $\begin{array}{l}\text { Perception and } \\
\text { combinations }\end{array}$ \\
& Target market segments & association \\
Results: & Choice & Reputation \\
Primary & Conative (behaviour) & Affective (attitude) \\
\multicolumn{1}{c}{ domain: } & & \\
\hline
\end{tabular}

Source: Modified after Boisen et al. (2018). 
ities, in order to identify knowledge gaps, methodological shortcomings and develop new measurement methods. We restricted the search to peer-reviewed publications accepted in scientific journals in the areas of marketing, tourism and hospitality, regional science and branding. Keywords were searched for in the title, abstract and text of potential articles. The initial search was carried out in the ISI Web of Science, Scopus, EBSCO and ProQuest databases, and returned 20 publications, of which about half did not discuss measurement and methodological issues related to quantifying the impact of place marketing activities. Hence, we widened the search to include books and websites, and Google Scholar was also used as a search engine in the extended search.

As books and websites were included in the sample, the extended search provided more studies on the measurement of place marketing activities. In total, 28 peerreviewed journal articles, 14 books, 7 conference papers, 2 chapters in edited volumes, 5 working papers, and 1 home page were found which discussed the measurement of place marketing activities in one way or another. Of these, 25 sources explicitly discussed measurement issues and were included in the reviewed sample.

\section{The methodology of measurement}

Several methods of measuring the effects of place marketing activities can be found in the literature. An overwhelming majority of the studies that measure the effects of place marketing activities are qualitative in nature and usually based on interviews, and only a few studies propose quantitative methods. Most studies measuring the effect of place marketing activities are case studies, followed by ex ante/ex post comparisons. Benchmarking methods and quasi-experimental approaches are also carried out but are not very common. A summary of the reviewed studies is presented in Table 2.

Kotler et al. (Kotler et al., 1999, 1993, 2002) propose a simple method of measurement addressing the situation before and after the place marketing activity. This approach is also used in studies by Meester and Pellenbarg (2001), Niedomysl (2007), Kozma (2009), Braun (2008), Rainisto (2003), Goovaerts et al. (2014), Dawson et al. (2011), Giles et al. (2012), Dinis (2004), and Zenker et al. (2014)., and even standard undergraduate textbooks teach this methodology for measuring the effects of marketing activities (Hudson \& Hudson, 2017; Kotler et al., 2014; Veal, 2018).

Parker et al. (2015) use a methodology close to the classical quasi-experiment to measure the image of a place before and after a place marketing activity. An observation $\left(\mathrm{O}_{1}\right)$ is made before an intervention is made in this case, a place marketing activity - and then an observation is made after the intervention $\left(\mathrm{O}_{2}\right)$. If the results between the experimental and control groups differ, the difference is assumed to be caused by the intervention, i.e. in this case the place marketing activity (Table 3).

Pergelova and Ruiz (2011) present a benchmarking model, which allows cities to be compared in terms of the deployment of different resources (e.g., access to markets, qualified labour force, infrastructure, and

Table 2. Reviewed studies.

\begin{tabular}{|c|c|c|c|c|c|c|c|}
\hline Study & ex-post/ex-ante & quasi-experiment & other & benchmarking & case study & Qualitative & Quantitative \\
\hline Kotler et al. (1993), (1999), 2002) & Yes & & & & Yes & Yes & \\
\hline Meester and Pellenbarg (2001) & Yes & & & & & Yes & \\
\hline Niedomysl (2007) & Yes & & & & & Yes & \\
\hline Kozma (2009) & Yes & & & & & Yes & \\
\hline Braun (2008) & Yes & & & & Yes & Yes & \\
\hline Rainisto (2003) & Yes & & & & Yes & Yes & \\
\hline Zenker and Martin (2011) & & & Yes & & & Yes & \\
\hline Zenker and Braun (2015) & & & Yes & & & Yes & \\
\hline Pergelova and Ruiz (2011) & & & & Yes & & & Yes \\
\hline Kotler et al. (2014) & Yes & & & Yes & Yes & Yes & \\
\hline Goovaerts et al. (2014) & Yes & & & & & & Yes \\
\hline Dawson et al. (2011) & Yes & & & & Yes & Yes & \\
\hline Giles et al. (2012) & Yes & & & & Yes & Yes & \\
\hline Dinis (2004) & Yes & & & & Yes & Yes & \\
\hline Zenker et al. (2014) & Yes & & & & & & Yes \\
\hline Parker et al. (2015) & & Yes & & & & & Yes \\
\hline Kneafsey (2000) & & & & & Yes & Yes & \\
\hline Marková and Boruta (2012) & & & & & Yes & Yes & \\
\hline Navrátil et al. (2009) & & & & & Yes & & Yes \\
\hline Heldt Cassel (2008) & & & & & Yes & Yes & \\
\hline Rozhkov and Skriabina (2015) & & & & Yes & Yes & Yes & \\
\hline Aiello and Donvito (2006) & & & & & Yes & Yes & \\
\hline \multicolumn{8}{|l|}{ Shibli and Coleman (2005) } \\
\hline Naidoo et al. (2011) & & & & & Yes & Yes & \\
\hline Asnawi et al. (2018) & & & Yes & & & & Yes \\
\hline
\end{tabular}


Table 3. Classical experimental design.

\begin{tabular}{lccc}
\hline & Pre-intervention & Intervention & Post-intervention \\
\hline Experimental group & $\mathrm{O}_{1}$ & $X$ & $\mathrm{O}_{2}$ \\
Control group & $\mathrm{O}_{1}$ & & $\mathrm{O}_{2}$ \\
\hline
\end{tabular}

Source: own elaboration

attitudes towards entrepreneurs), in order to examine certain objectives of place marketing. In this approach, the main implication for practitioners is that place marketing should be managed as a process, taking into account both resource flows and outputs, as well as the efficiency of the process. If practitioners only pay attention to place marketing objectives, they will spend significant resources, and thus be inefficient in their place marketing efforts. Conversely, if practitioners are only interested in the minimum use of resources, they will obtain low levels of impact. In the reviewed literature, Kotler et al. (2014) and Rozhkov and Skriabina (2015) use bench marketing approaches to measure the effect of place marketing activities, and the latter paper also constructs a benchmarking typology for measuring the effects of place marketing activities.

Two approaches are classified as "other" when it comes to how to measure place marketing activities. Zenker and Martin (2011) criticize the use of KPI's (e.g., tourist overnights and press clippings) when measuring the effects of place marketing activities as being too simple. Moreover, they view that the effects of place marketing activities are not measured on a regular basis and argue that to achieve a comprehensive measurement of place marketing effects, more advanced models must be used. According to Zenker and Martin (2011), "consumercentred" models are superior means to measure the effect of place marketing activities. The nature of consumer-centricity "lies not in how to sell products but rather in creating value for the consumer and, in the process, creating value for the firm; in other words, consumer-centricity is concerned with the process of dual value creation" (Shah et al., 2006: 115).

In the first of the two models proposed by Zenker and Martin (2011: 36), the Citizen Equity model estimates the "citizen's value to the place based on predicted future transactions and predicted future costs. Future transactions can be made operationally feasible in terms of consumer taxes: the tax revenues of present and potential customers from the central source of a place's income and become the basis for place actions". However, no indicators or formal model is presented to demonstrate the potential superiority of this evaluation model.

The second model proposed by Zenker and Martin (2011) is the Citizen Satisfaction model, where the actual behaviour of the target group is surveyed. Depending on how satisfied a target group is with a certain place (this particular case focussing on residents), the more or less likely they are to move. If they decide to move, a place where their satisfaction will increase relative to the place of origin, will be the target destination for them to head for.

Case studies reveal a multifaceted range of methodological issues. A case study is a research method involving an up-close, in-depth and detailed examination of the subject of study, concerning both the case, as well as its related contextual conditions. Case studies can be both qualitative and quantitative in character and may consist of single-case studies and comparisons of multiple cases (Yin, 2013). Case studies can be based on theoretical reasoning, but also be descriptive in nature (Mills et al., 2010). Four different types of case study approaches have been identified: (1) without any theory, focusing on a description of the studied cases; (2) a case study that fills knowledge gaps and holes, and that is based on positivist assumptions; (3) case studies designed to deal with a particular social construction of reality; and (4) case studies used to identify "anomalies" (Ridder, 2017). However, there are significant methodological differences between these approaches in terms of case study design.

A majority of the papers reviewed in this study claim to be case studies, and it is generally clear if a single or multiple case have been studied, and whether qualitative or quantitative methods are used. However, an overwhelming majority of these case studies contain no theory when discussing the analysed case/cases, and several are mere ex ante/ex post comparisons (see Table 2). Subsequently, the methodological individualism employed makes any generalization for recommending "best" or "good" practices difficult.

\section{Implications of the measurement methodologies}

At least three distinct implications of the quasiexperimental method and ex ante/ex post comparisons can be identified. Firstly, there is a linear relationship between the place marketing activities $x$ and the observable results y (see Figure 1, example 1), where no other aspects influence the results. However, this is hardly a reasonable assumption, and other aspects $(\mathrm{z})$ most likely impact the process in different ways (see Figure 1, examples 2-5).

This problem is well-known. For example, in the paper of Braun (2008), while four hypotheses were proved true in four individual cases, despite the author admitting that there were likely to be more factors involved than were reported in the study, he still proceeded to draw 


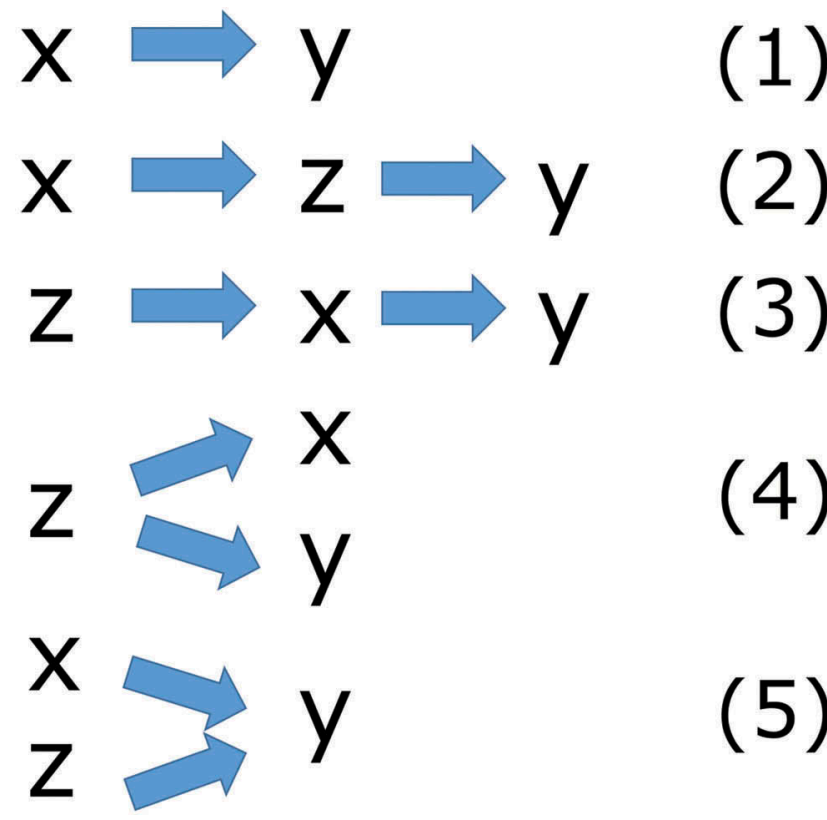

Figure 1. Possible theoretical causalities between the dependent variable $y$ and the independent variables $x$ and $z$.

Source: Own elaboration

implicitly generalizable conclusions. Braun (2008) then notes that as the research is explorative, you cannot exclude the potential for more factors to be involved, but persists in stating that the findings support the proposed hypotheses.

Many studies have concluded that place marketing is a part of a local or regional policy process, which raises the potential for influence on other aspects (Berglund \& Olsson, 2010; Deffner \& Metaxas, 2008; Heldt Cassel, 2008; Metaxas, 2007; Rauhut Kompaniets, 2018; Sidali et al., 2015; Van der Borg, 2008). Although other aspects ( $z$ in Figure 1) may have influenced the outcome, if there is a direct linear causality $(x \rightarrow y)$, then the intervention has had the desired impact.

Secondly, the assumed linear relationship in the quasi-experimental evaluation model and comparisons between ex ante/ex post results offers potential to identify "good" or "best" practices. Rauhut Kompaniets and Rauhut (2016) note that these practices are basically a copy-paste strategy which focus on activities rather than achievement. Three distinctive methodological problems can be identified here:

(1) We can see if something works - or not - but we cannot understand why, due to a lack of theory;

(2) The methodologies of "good" or "best" practice violate all types of threats to what is called validity, i.e. whether the intervention is implemented in view of the theoretical concept as intended;
(3) The methodologies of "best" and "good" practice ignore the problems of reliability, i.e. to what extent the findings can be generalized for all situations of a similar kind.

Whether the "best practice" approach works in another context is of less importance than the fact that the checklist has been ticked off in accordance with the instructions (Rauhut Kompaniets \& Rauhut, 2013, 2016). Especially, the diagnostics and planning emphasized by Kotler et al. (1999) cannot be seen to be done properly (if at all) if following the "good" or "best" practice methodology.

As a third issue, the context and 'black box'1 of cases are ignored and hence do not appear to have an influence on the outcome of the intervention. This implication raises doubts as to the use of the quasiexperimental evaluation model, and also ex ante/ex post comparisons. Several scholars have shown that place marketing is used as a governance strategy for managing perceptions about regions, cities and towns (see, e.g.,, Eshuis et al., 2013; Kasabov \& Sundaram, 2013; Kavaratzis \& Hatch, 2013). Place marketing is primarily about policies, and a close cooperation with stakeholders is needed (Boisen et al., 2018). In fact, place marketing is dependent on the political system and governance structures, and hence can be seen as being highly political (Parker et al., 2018; Kavaratzis \& Ashworth, 2008; Rauhut Kompaniets, 2018).

In order to understand and explain why an intervention succeeds or fails we simply need to understand what happens in "the black box", i.e. the processes leading to certain impacts. Consequently, theory is needed to explain why a particular intervention leads to a desired or undesired result (Astbury \& Leeuw, 2010). The evidence for implementing a certain intervention is however very dependent on contextual aspects, which explains why an intervention may be successful in one context, but a complete failure in another (Timmins \& Miller, 2007).

Hence, place marketing activities will be put into a political "black box" process, in which their contextual factors play a significant role, and the actual outcome is highly unpredictable. This results in a situation where a "best practice" approach with a checklist to be ticked off in accordance with instructions simply will not work, because the contexts in which the place marketing or place branding activities are implemented are fundamentally different.

The Citizen Equity model by Zenker and Martin (2011) is an abstract theoretical construct, and it can be questioned as to what extent this model can be operationalized in measuring the impact of place marketing activities. Moreover, Zenker and Martin (2011) present the Citizen Satisfaction model as a novel finding, but in 
fact the "model" is very similar to the standard neoclassical micro theory of migration: namely where the individual evaluates the costs and benefits of staying at place $X$, with the costs and benefits of moving to place $Y$, and if the costs are lower and benefits higher for place $Y$ than place $X$, then the individual will move (Massey et al., 1993; Schoorl, 1995).

The model presented by Pergelova and Ruiz (2011) is an advanced statistical model, yet the model is a theoretical construct and the authors provide no empirical evidence for its superiority in measuring the effects of place marketing activities. We have not found any empirical studies that use this model, so we cannot express a view as to how well it predicts the impact of place marketing activities. Nevertheless, Pergelova and Ruiz (2011) return frequently to the issue of the model being useful for practitioners (and implicitly stakeholders) in their paper, which is seen as positive. However, the "benchmarking" character of the model is seen as negative, as it aims to produce a general model for identifying "best practices". As concluded earlier, "one-size-fits-all" models struggle with problems related to validity and reliability.

\section{Place marketing as policy analysis}

Several scholars have emphasized that place marketing is about policies and involves a close cooperation with stakeholders (Anholt, 2008; Boisen et al., 2018; Page \& Hall, 2003; Parker et al., 2015; Rauhut Kompaniets, 2018; Skinner, 2010; Warnaby \& Medway, 2013). Metaxas (2007) discussed how Malta has chosen to use place marketing as a strategic instrument, and how it is used as a planning tool. It means that politicians who decide to place market will reach a political decision to do so before using taxpayers' money. Hence, stakeholders will already be involved from the beginning of the place marketing process.

Since place marketing activities are about politics and policies at a local level, as concluded above, the budget allocation for this activity follows the normal political process: i.e. the allocated budget will be negotiated and the outcome depends on the bargaining strength of the involved actors, political priorities, etc. (Pawson \& Tilley, 1997; Premfors, 1989). Moreover, the place marketing activities will be characterized by vaguely defined aims and be of a qualitative nature, and any indicators will be vaguely defined (Bardach \& Patashnik, 2020; Vedung, 2009). It is not in the interests of the ruling majority of a city/region/place to have KPI's that might indicate a massive failure or inefficient use of resources. Hence, we conclude that it is hard to identify any linear causality between place marketing activities and improvements in KPI's because place marketing is such a highly politicized activity. But despite this conclusion, we argue that it is still possible to evaluate both the processes and outcomes of place marketing activities.

There is an extensive amount of literature on policy evaluations, and some of the approaches may even be useful for evaluating such a highly politicized activity such as place marketing (Bamberger et al., 2004; Bengston \& Fan, 1999; Fine et al., 2000; Foss Hansen, 2005; Mohr, 1999; Newcomer, 2001; Pratt et al., 2000; Trochim, 2009; Van der Knaap, 1995; Weimer \& Vining, 1992). We argue that an appropriate evaluation method that measures the impact of place marketing activities may effectively help to overcome any shortcomings that are identified.

\section{A way out of the woods?}

In this section, we will outline an alternative to ex ante/ ex post comparisons, quasi-experimental evaluation models, and the numerous case studies that have proposed to serve as benchmarks of "good" or "best" practice. Evidence-based evaluation models measure the impact of an intervention by looking at the causality, namely: input $\rightarrow$ output $\rightarrow$ outcome $\rightarrow$ impact (Hospes, 2008). In order to understand and explain why an intervention succeeds or fails, we simply need to understand what happens in "the black box", i.e. the processes that lead to certain impacts (Astbury \& Leeuw, 2010).

This argument is not only true for understanding and explaining the impacts of an intervention, but it can also be used to understand and explain why a particular problem occurs in one context, yet not in another (despite that all of conditions for implementing the intervention appear to be fulfilled). Pawson and Tilley (1997) have developed a theoretically based evaluation method termed as Realistic Evaluation, which not only focuses on what results an intervention has, but also why this particular result was the outcome and what importance the context has for a certain intervention. While a quasiexperimental evaluation model and ex ante/ex post comparisons do not control for context, nor can they explain why an intervention works or does not work, Realistic evaluation tries to find the contextual aspects that make interventions effective, and hence generate knowledge and support for political decision-making.

Three aspects need to be analysed when an evaluation is made of a certain intervention in a given context (Tilley, 1998): (a) Mechanism: what is it about a measure that may lead it to have a particular outcome in a given context?, (b) Context: what conditions are needed for a measure to trigger mechanisms to produce particular 


\section{Evidence oriended evaluation}

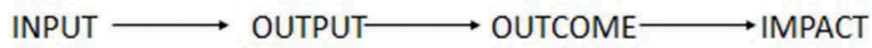

\section{Realistic evaluation}

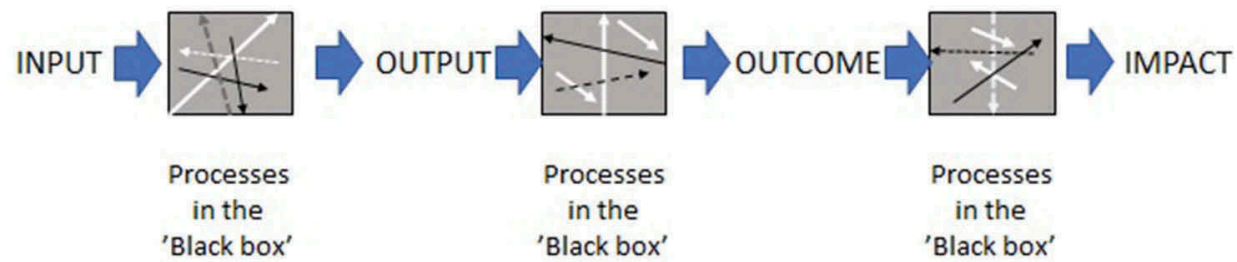

Figure 2. Two perspectives on causality.

Source: Modified after Hospes (2008)

regularity patterns?, and (c) Regularity: what are the practical effects (impact) produced by causal mechanisms being triggered in a given context?

Pawson and Tilley (1997) describe the procedure followed in the implementation of realist evaluation techniques in programme evaluation, and emphasize that once hypothesis have been generated and data collected, the outcomes of the programme are explored, focusing on groups that the programme benefitted and those who did not benefit. The effectiveness of a programme is thus not dependent on outcomes alone (cause-effect), but rather there is a consideration of the theoretical mechanisms that are applied, and the socio-historical context in which the programmes were implemented. Thus, the final explanation of a programme considers context, mechanism, and outcome (Pawson \& Tilley, 1997).

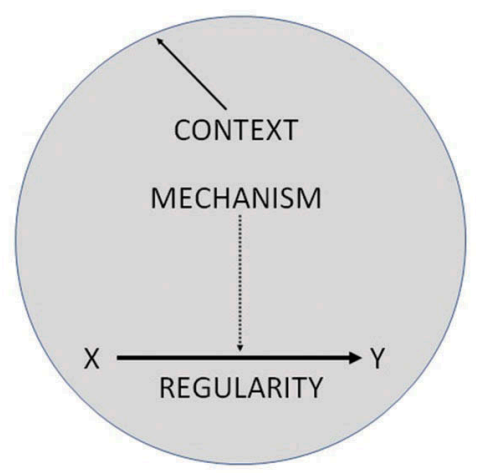

Figure 3. Central aspects in the 'Realistic evaluation' method. Source: Pawson and Tilley (1997).
The "Realistic Evaluation" model has several methodological strengths. It can be successfully be used when evaluating programmes on, for example, changes in the public sector. The method also works well when evaluating problems of a technical nature, as well as 'soft values' such as, e.g., education, health care and social problems (Sager, 2008; Holma \& Kontinen, 2011; Holm Pedersen \& Rieper, 2008; Wand et al., 2010; Rycroft-Malone et al., 2010; Greenhalgh et al., 2009; Manzano-Santaella, 2009; Byng et al., 2005). It is possible to use the method when evaluating total interventions and when conducting case studies (Kœnig, 2009), and also to see how practice develops and works within organizations (Wilson \& McCormack, 2006). The "Realistic Evaluation" model is especially suitable for analysing how practitioners adopt and use new methods in small communities under a pressure to adapt to change (Lhussier et al., 2008).

The realistic evaluation method can be successfully implemented for place marketing activities. In published research, it is established that a place marketing activity that leads to successful and desired results in one context, may not in another. This issue is addressed by analysing what Pawson and Tilley (1997) refer to as mechanisms. Successful place marketing activities need to identify what conditions are needed for a measure to trigger mechanisms to produce particular regularity patterns. This includes policy aspects, to what extent the diagnostics and planning issues emphasized by Kotler et al. (1999) are done properly or not, whether optimal unique selling points have been chosen, if the correct target audience has been identified, etc. All of these aspects address issues that Pawson and Tilley (1997) term as context. 
A third aspect to be analysed for a certain intervention implemented in a given context is regularity (Pawson \& Tilley, 1997). Regularity can illuminate the practical outcome(s) produced by causal mechanisms that are triggered in a given context. In plain words, we will be able to understand how and why something works or not, and this is exactly what any measurement of place marketing activities should be able to do.

There are two additional strengths of the realistic evaluation method. Firstly, it allows us to see to what extent the intervention is implemented in regard to the intended theoretical concept being displayed. In other words, the validity of the results will be controlled for. Secondly, it allows us to assess as to what extent the findings are transferable and can be generalized to situations of a similar kind, meaning that the model controls for reliability. By using such an evaluation method when measuring the effects of place marketing, the stakeholders involved will be able to reassure themselves that they are getting good value for their money.

\section{Concluding remarks}

Place marketing is "political" and policy oriented. This highlights the need to understand what happens in the policy process and context in which the place marketing activities take place: i.e. we need to open the "black box" to understand why and how some activities do or do not work. Simple ex ante/ex post comparisons and the quasi-experimental model are unable to offer us a means to satisfactorily understand this issue, and moreover, the linear causality in these evaluation models can be questioned. Quasi-experimental models and ex ante/ex post comparisons are seen as good starting points for establishing "best practices", but although we can observe if an intervention leads to a particular change, we cannot understand why this has occurred as there is no theory to explain it. Furthermore, "best practices" violate the significant scientific concepts of validity and reliability, and are easily reduced to being a checklist to be ticked off. So, while this can tell us to what extent a particular checklist works in a particular context, it is of lesser importance when looking to measure the impact of place marketing activities in general.

Place marketing has become a lucrative field for private sector consultants who may have little or no interest in empirical evidence or theory (Herezniak et al., 2018; Niedomysl \& Jonasson, 2012; Parker et al., 2015; Skinner, 2010; Vuignier, 2017; Warnaby \& Medway, 2013). Moreover, when practitioners and politicians ask for "best practice" solutions, this suggests that evidencebased knowledge is put aside (Rauhut Kompaniets \&
Rauhut, 2016), and to ignore evidence-based knowledge may serve political purposes. These two aspects may explain the use of questionable evaluation methodologies when measuring the impact of place marketing activities.

In this paper, we have taken initial steps towards identifying an efficient method for measuring the impact of place marketing activities. Our findings highlight the Realistic Evaluation method as a means to control for the central aspects of place marketing. While objections can be raised against both the framework and the propositions, our aim has been to illustrate that a few issues considered central to the understanding of the impact measurement of place marketing can be singled out, and formulated in such a way that allows for empirical testing using the current methods of measurement. In order to drive forward future research in this area, there is a need to identify place marketing KPI's and link them to the Realistic Evaluation method. Once this is done, it will then be possible to test this method empirically. A second future research action will be to compare ex ante/ex post comparisons, the quasi-experimental model, and the Realistic Evaluation model, in the context of place marketing activities, in order to improve our understanding of some of the fundamentals of place marketing.

\section{Note}

1. In public administration, the "black box" refers to a hidden process or procedure where we can see the input and output, but we do not know how the decisions were made.

\section{Acknowledgments}

The authors are grateful for the constructive comments offered by the two anonymous referees of this journal and the journal editor.

\section{Disclosure statement}

No potential conflict of interest was reported by the authors.

\section{ORCID}

Daniel Rauhut (ID) http://orcid.org/0000-0002-9146-9984

Olga Rauhut Kompaniets (iD) http://orcid.org/0000-0001-63637066

\section{References}

Aiello, G., \& Donvito, R. (2006). The Role of Integrated Communication with Place Marketing: The Province of Florence Case. In 22nd Annual IMP Conference, Milan (pp. 7-9). 
Andersson, I. (2014). Placing place branding: An analysis of an emerging research field in human geography. Danish Journal of Geography, 114(2), 143-155.

Anholt, S. (2008). Place branding: Is it marketing or isn't it? Place Branding and Public Diplomacy, 4(1), 1-6. https://doi. org/10.1057/palgrave.pb.6000088

Ashworth, G. J., \& Goodall, B. (Eds.). (1990). Marketing tourism places. Routledge.

Ashworth, G. J., \& Voogd, H. (1990). Selling the city: Marketing approaches in public sector urban planning. Belhaven Press.

Asnawi, A., Kartini, D., Afiff, F., \& Rufaidah, P. (2018). City marketing: Scale development and measurement indicators applicated to Maluku province- Indonesia". Cogent Business \& Management, 5(1525827), 1-15. https://doi.org/10.1080/ 23311975.2018.1525827

Astbury, B., \& Leeuw, F. L. (2010). Unpacking Black Boxes: Mechanisms and Theory Building in Evaluation. American Journal of Evaluation, 31(3), 363-381. https://doi.org/10. 1177/1098214010371972

Bamberger, M., Rugh, J., Church, M., \& Fort, L. (2004). Shoestring evaluation: Designing impact evaluation under budget, time and data constraints. American Journal of Evaluation, 25(1), 5-37. https://doi.org/10.1177/ 109821400402500102

Bardach, E., \& Patashnik, E. M. (2020). A Practical Guide for Policy Analysis. Sage.

Bengston, D. N., \& Fan, D. P. (1999). An innovative method for evaluating strategic goals in a public agency: Conservation leadership. Evaluation Review, 23(1), 77-710. https://doi.org/ $10.1177 / 0193841$ X9902300104

Berglund, E., \& Olsson, K. (2010). Rethinking place marketing A literature review, Paper presented at the 50th Anniversary European Congress of the Regional Science Association International, Jönköping, Sweden, 19th - 23rd August, 2010.

Boisen, M., Terlouw, K., Groote, P., \& Couwenberg, O. (2018). Reframing place promotion, place marketing, and place branding - Moving beyond conceptual confusion. Cities, 80, 4-11. https://doi.org/10.1016/j.cities.2017.08.021

Braun, E. (2008). City Marketing: Towards an integrated approach. PhD Thesis, Erasmus University Rotterdam.

Braun, E., \& Zenker, S. (2010). Towards an Integrated Approach for Place Brand Management, Paper presented at the 50th European Regional Science Association Congress, Jönköping, Sweden, 19th - 23rd August, 2010.

Buss, C. (2013). Obstacles in Place Marketing: Solutions for Your Target Groups. Public Administration Review, 73(3), 516-517. https://doi.org/10.1111/puar.12061

Byng, R., Norman, I., \& Redfern, S. (2005). Using Realistic Evaluation to Evaluate a Practice-level Intervention to Improve Primary Healthcare for Patients with Long-term Mental Illness. Evaluation, 11(1), 69-93. https://doi.org/10. 1177/1356389005053198

Dawson, D., Fountain, J., \& Cohen, D. A. (2011). Place-based Marketing and Wine Tourism: Creating a Point of Difference and Economic Sustainability for Small Wineries, Paper presented at the 6th AWBR International Conference, 9-10 June 2011 in Bordeaux, France.

Deffner, A., \& Metaxas, T. (2008). What are Public Relations doing in a 'Place' Like Place Marketing? A Proposed Public Relations Plan (PRP) for the Region of Kainuu, Finland. University of Thessaly, Discussion Paper Series, 14(16): 299-306.
Dinis, A. (2004). Territorial marketing: A useful tool for competitiveness of rural and peripheral areas, Paper presented at the 44th Congress of the European Regional Science Association, 25-29 August 2004 in Porto, Portugal.

Eshuis, J., Braun, E., \& Klijn, E. H. (2013). Place Marketing as Governance Strategy: An Assessment of Obstacles in Place Marketing and Their Effects on Attracting Target Groups. Public Administration Review, 73(3), 507-516. https://doi. org/10.1111/puar.12044

Eshuis, J., Klijn, E. H., \& Braun, E. (2014). Place marketing and citizen participation: Branding as strategy to address the emotional dimension of policy making? International Review of Administrative Sciences, 80(1), 151-171. https:// doi.org/10.1177/0020852313513872

Fine, A. H., Thayer, C. E., \& Coghlan, A. T. (2000). Program evaluation practice in the non-profit sector. Non-profit Management and Leadership, 10(3), 331-339. https://doi. org/10.1002/nml.10309

Florek, M. (2012). Measurement of city branding equity. Actual Problems of Economics, 2(7), 130-139.

Florek, M., Herezniak, M., \& Augustyn, A. (2019). You can't govern if you don't measure: Experts' insights into place branding effectiveness assessment. Journal of Place Management and Development, 12(4), 545-565. https://doi. org/10.1108/JPMD-10-2018-0074

Foss Hansen, H. (2005). Choosing evaluation models. A discussion on evaluation design. Evaluation, 11(4), 447-462. https://doi.org/10.1177/1356389005060265

Gertner, D. (2011a). A (tentative) meta-analysis of the 'place marketing' and 'place branding' literature. Journal of Brand Management, 19(2), 112-131. https://doi.org/10.1057/bm. 2011.13

Gertner, D. (2011b). Unfolding and configuring two decades of research and publications on place marketing and place branding. Place Branding and Public Diplomacy, 7(2), 91-106. https://doi.org/10.1057/pb.2011.7

Giles, E. L., Bosworth, G., Willett, \& Willett, J. (2012). The role of local perceptions in the marketing of rural areas. Journal of Destination Marketing and Management, 2(1), 4-13. https:// doi.org/10.1016/j.jdmm.2012.11.004

Goovaerts, P., van Biesbroeck, H., \& van Tilt, T. (2014). Measuring the effect and efficiency of city marketing. Procedia Economics and Finance, 12, 191-198. https://doi. org/10.1016/S2212-5671(14)00335-9

Govers, R. (2011). From place marketing to place branding and back. Place Branding and Public Diplomacy, 7(4), 227-231. https://doi.org/10.1057/pb.2011.28

Greenhalgh, T., Humphrey, C., Hughes, J., Macfarlane, F., Butler, C., \& Pawson, R. (2009). How Do You Modernize a Health Service? A Realist Evaluation of Whole-Scale Transformation in London. The Milbank Quarterly, 87(2), 391-416. https://doi.org/10.1111/j.1468-0009.2009.00562.x

Hankinson, G. (2015). Rethinking the place branding construct. In M. Kavaratzis, G. Warnaby, \& G. J. Ashworth (Eds.), Rethinking place branding: Comprehensive brand development for cities and regions. Springer.

Heldt Cassel, S. (2008). Trying to be attractive: Image building and identity formation in small industrial municipalities in Sweden. Place Branding and Public Diplomacy, 4(2), 102-114. https://doi.org/10.1057/palgrave.pb.6000086

Herezniak, M., \& Anders-Morawska, J. (2015). City brand strategy evaluation: In search of effectiveness indicators". Journal 
of Place Management and Development, 8(3), 187-205. https://doi.org/10.1108/JPMD-06-2015-0023

Herezniak, M., Florek, M., \& Augustyn, A. (2018). On measuring place branding effectiveness. Between theoretical developments and empirical findings. Economics and Sociology, 11(2), 36-51. https://doi.org/10.14254/2071789X.2018/11-2/3

Holm Pedersen, L., \& Rieper, O. (2008). Is Realist Evaluation a Realistic Approach for Complex Reforms? Evaluation, 14 (3), 271-293. https://doi.org/10.1177/1356389008090856

Holma, K., \& Kontinen, T. (2011). Realistic evaluation as an avenue to learning for development NGOs. Evaluation, 17 (2), 181-192. https://doi.org/10.1177/1356389011401613

Hospes, O. (2008). Evaluation evolution? Three approaches to evaluation. [accessed 20 March, 2020] http://www.thebroker online.eu/Articles/Evaluation-evolution

Hudson, S., \& Hudson, L. (2017). Marketing for Tourism, Hospitality and Events. In Sage.

Jorgensen, O. H. (2015). Developing a city brand balance sheet - Using the case of Horsens, Denmark. Place Branding and Public Diplomacy, 11(1), 148-160. https://doi. org/10.1057/pb.2014.16

Kasabov, E., \& Sundaram, U. (2013). A Stakeholder Approach to Branding Clusters: Pointers to a Research Agenda. Regional Studies, 47(4), 530-543. https://doi.org/10.1080/00343404. 2011.631907

Kavaratzis, M. (2008). From City Marketing to City Branding: An Interdisciplinary Analysis with Reference to Amsterdam, Budapest and Athens1. PhD Thesis, Rijksuniversiteit Groningen.

Kavaratzis, M., \& Ashworth, G. J. (2008). Place marketing: How did we get here and where are we going? Journal of Place Management and Development, 1(2), 150-165. https://doi. org/10.1108/17538330810889989

Kavaratzis, M., \& Hatch, M. J. (2013). The dynamics of place brands: An identity-based approach to place branding theory. Marketing Theory, 13(1), 69-86. https://doi.org/10. $1177 / 1470593112467268$

Klijn, E.-H., Eshuis, J., \& Braun, E. (2012). The Influence of Stakeholder Involvement on the Effectiveness of Place Branding. Public Management Review, 14(4), 499-519. https://doi.org/10.1080/14719037.2011.649972

Kneafsey, M. (2000). Tourism, Place Identities and Social Relations in the European Rural Periphery. European Urban and Regional Studies, 7(1), 35-50. https://doi.org/10.1177/ 096977640000700103

Kœnig, G. (2009). Realistic Evaluation and Case Studies. Stretching the Potential. Evaluation, 15(1), 9-30. https://doi. org/10.1177/1356389008097869

Kotler, P., Asplund, C., Rein, I., \& Haider, D. (1999). Marketing Places Europe. Prentice-Hall.

Kotler, P., Bowen, J. T., \& Makens, J. C. (2014). Marketing for Hospitality and Tourism.

Kotler, P., Haider, D. H., \& Rein, I. (1993). Marketing Places: Attracting Investment, Industry and Tourism to Cities, States and Nations. The Free Press.

Kotler, P., Hamlin, M. A., Rein, I., \& Haider, D. H. (2002). Marketing Asian Places Attracting Investment, Industry and Tourism to Cities, States and Nations. John Wiley \& Sons.

Kozma, G. (2006). Place Marketing. PhD Thesis, University of Debrecen.
Kozma, G. (2009). Place marketing in Hungary: The case of Debrecen. European Spatial Research and Policy, 16(1), 59-74. https://doi.org/10.2478/v10105-009-0004-6

Lhussier, S. M., Carr, S. M., \& Robson, A. (2008). The Potential Contribution of Realistic Evaluation to Small-Scale Community Interventions. Community Practitioner, 81(9), 25-28.

Lucarelli, A. (2012). Unraveling the complexity of 'city brand equity': A three-dimensional framework. Journal of Place Management and Development, 5(3), 231-252. https://doi. org/10.1108/17538331211269648

Lucarelli, A., \& Berg, P. O. (2011). Citybranding: A state-of-theart review of the research domain. Journal of Place Management and Development, 4(1), 9-27. https://doi.org/ 10.1108/17538331111117133

Mant, J. (2008). Place management as a core role in government. Journal of Place Management and Development, 1(1), 100-108. https://doi.org/10.1108/ 17538330810865363

Manzano-Santaella, A. (2011). A realistic evaluation of fines for hospital discharges: Incorporating the history of programme evaluations in the analysis. Evaluation, 17(1), 21-36. https:// doi.org/10.1177/1356389010389913

Marková, B., \& Boruta, T. (2012). The Potential of Cultural Events in the Peripheral Rural Jesenicko Region. AUC Geographica, 47(2), 45-52. https://doi.org/10.14712/23361980.2015.16

Marques da Costa, E., Palma, P., Rauhut, D., Humer, A., Constantin, D., \& Velasco, X. (2013). What Indicators to Use when Measuring Services of General Interest? Europe Xxi, 23, 7-28. https://doi.org/10.7163/Eu21.2013.23.1

Massey, D. S., Arango, J., Hugo, G., Kouaouci, A., Pellegrino, A., \& Taylor, J. E. (1993). Theories of International Migration: A Review and Appraisal. Population and Development Review, 19(3), 431-466. https://doi.org/10.2307/2938462

Meester, W. J., \& Pellenbarg, P. H. (2001). Changing regional images: Are regional marketing campaigns successful?, Paper prepared for the 41st European Congress of the Regional Science Association Zagreb

Metaxas, T. (2007). Place marketing, strategic planning and competitiveness: The case of Malta. Discussion Paper Series 13(20),449-476.

Metaxas, T. (2010) Planning, managing and implementing place/city marketing effectively: Review and discussion of the last 25 years. MPRA Paper No. 41024.

Metaxas, T., \& Kallioras, D. (2004). Medium Sized cities' economic development and regional competitiveness: The case of Larissa-Volos dipole in Thessaly region of Greece. Discussion Papers Series, 10(7), 161-200.

Mills, A. J., Durepos, G., \& Wiebe, E. (Eds.). (2010). Encyclopedia of Case Study Research. Sage.

Mohr, L. B. (1999). The qualitative method of impact analysis. American Journal of Evaluation, 20(1), 69-84. https://doi.org/ 10.1177/109821409902000106

Naidoo, P., Ramseook-Munhurrun, P., \& Seetaram, A. K. (2011). Marketing the Hotel Sector in Economic Crisis. Evidence from Mauritius. Global Journal of Business Research, 5(2), $1-12$.

Navrátil, J., Martinát, S., \& Kallabová, E. (2009). Framework for utilizing angling as a tourism development tool in rural areas. Agricultural Economics - Czech, 55(10), 508-518. https://doi.org/10.17221/2622-AGRICECON 
Newcomer, K. E. (2001). Tracking and probing program performance: Fruitful path or blind alley for evaluation professionals? American Journal of Evaluation, 22(3), 337-341. https://doi.org/10.1177/109821400102200308

Niedomysl, T. (2007). Promoting rural municipalities to attract new residents: An evaluation of the effects. Geoforum, 38(4), 698-709. https://doi.org/10.1016/j.geoforum.2006.11.024

Niedomysl, T., \& Jonasson, M. (2012). Towards a theory of place marketing. Journal of Place Management and Development, 5 (3), 223-230. https://doi.org/10.1108/17538331211269639

Page, S. J., \& Hall, C. M. (2003). Managing Urban tourism. Prentice Hall.

Parker, C., Roper, S., \& Medway, D. (2015). Back to basics in the marketing of place: The impact of litter upon place attitudes. Journal of Marketing Management, 31(9-10), 1090-1112. https://doi.org/10.1080/0267257X.2015.1035307

Parment, A. (2018). Marknadsföring ['Marketing']. Studentlitteratur.

Parmenter, D. (2007). Key Performance Indicators. John Wiley \& Sons.

Pawson, R., \& Tilley, N. (1997). Realistic Evaluation. Sage Publications.

Pergelova, A., \& Ruiz, L. F. A. (2011). Place Marketing Performance: Benchmarking European Cities as Business Destinations. Working Paper no. 1102, Universitat Autonoma de Barcelona.

Poskhart, R. (2014). A definition of the concept of economic effectiveness. Central Eastern European Journal of Management and Economics, 2(3), 179-187.

Pratt, C. C., McGuigan, W. M., \& Katzev, A. R. (2000). Measuring program outcomes: Using retrospective pretest methodology. American Journal of Evaluation, 21(3), 341-349. https://doi.org/10.1177/109821400002100305

Premfors, R. (1989). Policyanalys. Studentlitteratur.

Rainisto, S. (2003). Success Factors of Place Marketing: A Study of Place Marketing Practices in Northern Europe and the United States. PhD Thesis, Helsinki University of Technology.

Rauhut Kompaniets, O. (2018). A 'bottom-up' place marketing initiative: Destination Lund Sweden. In Proceedings of the 3rd International Place Branding and 6th Destination Branding and Marketing Conferences. Institute for Tourism Studies. 5-7 December 2018. 132-142.

Rauhut Kompaniets, O., \& Rauhut, D. (2013). Place Marketing and Rural Municipalities in Northern Sweden: A Content Analysis of Municipal Homepages. Romanian Journal of Regional Science, 7(2), 11-36.

Rauhut Kompaniets, O., \& Rauhut, D. (2016). Why Urban and Rural Place Marketing Strategies differ: A Theoretical Discussion. Romanian Journal of Regional Science, 10(1), 23-40.

Rauhut Kompaniets, O., \& Rauhut, D. (2017). Against all Odds? Applying the ' $5 \mathrm{P}^{\prime}$-Model in Place Marketing of Peripheral Areas, Paper prepared for the 57th conference of the European Regional Science Association, Groningen, the Netherlands, 29 August - 1 September 2017.

Ridder, H. G. (2017). The theory contribution of case study research designs. Business Research, 10(2), 281-305. https:// doi.org/10.1007/s40685-017-0045-z

Roberts, L., \& Hall, D. (2004). Consuming the countryside: Marketing for "rural tourism". Journal of Vacation Marketing, 10(3), 253-263. https://doi.org/10.1177/ 135676670401000305

Rozhkov, K. L., \& Skriabina, N. I. (2015). Places, users, and place uses: A theoretical approach to place market analysis.
Journal of Place Management and Development, 8(2), 103-122. https://doi.org/10.1108/JPMD-10-2014-0024

Rycroft-Malone, J., Fontenla, M., Bick, D., \& Seers, K. (2010). A realistic evaluation: The case of protocol-based care. Implementation Science, 5. https://doi.org/10.1186/17485908-5-38

Sager, F. (2008). Securing the long-term bases of the dual system: A realistic evaluation of apprenticeship marketing in Switzerland. Journal of Vocational Education \& Training, 60 (3), 327-341. https://doi.org/10.1080/13636820802305678

Schoorl, J. (1995). Determinants of International Migration: Theoretical Approaches and Implications for Survey Research. In R. van der Erf \& L. Heering (Eds.), Causes of International Migration. Eurostat.

Shah, D., Rust, R. T., Parasuraman, A., Staelin, R., \& Day, G. S. (2006). The path to customer centricity. Journal of Service Research, 9(2), 113-124. https://doi.org/10.1177/ 1094670506294666

Shibli, S., \& Coleman, R. (2005). Economic Impact and Place Marketing Evaluation: A Case Study of the World Snooker Championship. International Journal of Event Management Research, 1(1), 13-29.

Sidali, K. L., Kastenholz, E., \& Bianchi, R. (2015). Food tourism, niche markets and products in rural tourism: Combining the intimacy model and the experience economy as a rural development strategy. Journal of Sustainable Tourism, 23 (8-9), 1179-1197. https://doi.org/10.1080/09669582.2013. 836210

Skinner, H. (2010). The emergence and development of place marketing's confused identity. Journal of Marketing Management, 24(9-10), 915-928. https://doi.org/10.1362/ $026725708 \times 381966$

Tilley, N. (1998). Evaluating the effectiveness of CCTV schemes. In C. Norris, J. Moran, \& G. Armstrong (Eds.), Surveillance, Closed Circuit Television and Social Control. Ashgate.

Timmins, P., \& Miller, C. (2007). Making evaluations realistic: The challenge of complexity. Support for Learning, 22(1), 9-16. https://doi.org/10.1111/j.1467-9604.2007.00439.x

Trochim, W. M. K. (2009). Evaluation policy and evaluation practice. New Directions for Evaluation, 123, 13-32. https:// doi.org/10.1002/ev.303

van der Borg, J. (2008). Place Marketing, Governance and Tourism Development - Or How to Design the Perfect Regional Tourist Board? Ca' Foscari University of Venice, Dept. of Economics, Working Paper No. 04/WP/2008

Van der Knaap, P. (1995). Policy Evaluation and Learning. Feedback, Enlightenment or Augmentation? Evaluation, 1 (2), 189-216. https://doi.org/10.1177/135638909500100205

Veal, A. J. (2018). Research Methods for Leisure and Tourism. Pearson.

Vedung, E. (2009). Utvärdering $i$ politik och förvaltning. Studentlitteratur.

Vuignier, R. (2017). Place marketing and place branding 1976-2016: A multidisciplinary literature review. International Review on Public and Nonprofit Marketing, 14 (4), 447-473. https://doi.org/10.1007/s12208-017-0181-3

Wand, T., White, K., \& Patching, J. (2010). Applying a realist(ic) framework to the evaluation of a new model of emergency department based mental health nursing practice. Nursing Inquiry, 17(3), 231-239. https://doi.org/10.1111/j.1440-1800. 2010.00488.x 
Ward, S. V. (2004). Selling Places: The marketing and Promotion of Towns and Cities 1850-2000. Spon Press.

Warnaby, G., \& Medway, D. (2013). What about the 'place' in place marketing? Marketing Theory, 13(3), 345-363. https:// doi.org/10.1177/1470593113492992

Weimer, D. L., \& Vining, A. R. (1992). Policy Analysis: Concepts and Practice. Prentice Hall.

Weisbrod, G., \& Weisbrod, B. (1997). Assessing the Economic Impact of Transportation Projects. Transportation Research Circular No. 477. https://web.archive.org/web/ 20130928100819/http://onlinepubs.trb.org/Onlinepubs/cir culars/circular477.pdf [Accessed 20 March, 2020].

Wilson, V., \& McCormack, B. (2006). Critical realism as emancipatory action: The case for realistic evaluation in practice development. Nursing Philosophy, 7(1), 45-57. https://doi. org/10.1111/j.1466-769X.2006.00248.x

Yin, R. K. (2013). Case Study Research: Design and Methods. Sage. Zenker, S., \& Braun, E. (2015). Rethinking the measurement of place brands. In Kavaratzis, M., Warnaby, G., \& Ashworth, G. J. (Eds.), Rethinking place branding (p. 211-223). Springer.

Zenker, S., Gollan, T., \& van Quaquebeke, N. (2014). Using Polynomial Regression Analysis and Response Surface Methodology to Make a Stronger Case for Value Congruence in Place Marketing. Psychology and Marketing 31(3), 184-202. https://doi.org/10.1002/mar.20686

Zenker, S., \& Martin, M. (2011). Measuring Success in Place Marketing and Branding. Place Branding and Public Diplomacy, 7(1), 32-41. https://doi.org/10.1057/pb.2011.5 